\title{
Augmented Reality Model Framework for Maritime Education to Alleviate the Factors Affecting Learning Experience
}

\author{
Rommel E. Balcita and Thelma D. Palaoag
}

\begin{abstract}
The maritime industry in the Philippines had several deficiencies that must be addressed seriously in order to maintain strong reputation in producing competitive seafarers worldwide. This affects student's educational skills and knowledge before finishing their education and training. This research led in identifying several factors affecting learning experiences to be addressed by incorporating advance technologies to further enhance student's learning experiences. The learning strategies used in this study are focused on using presentation, multimedia, simulator and hands-on. But these are not enough to satisfy students craving to learn due to some constraints during learning. In this study most of the factors identified are from literatures, monitoring reports, previous surveys and studies conducted in one of the maritime institution north of the Philippines. A descriptive research method was applied with the 32 marine engineering third year students as the respondents. Results extracted from questionnaires revealed important points that must be considered on the different learning strategies. The learning experiences of students on the different learning strategy used in the learning process exposed several learning factors to be regulated. The findings suggest that there is still an opportunity of improvement on student's learning experiences by introduction emerging advance technology by developing an augmented reality model framework to enhance learning experiences.
\end{abstract}

Index Terms-Augmented reality, education, learning, visual technology.

\section{INTRODUCTION}

Seafaring is one of the most popular and lucrative job and career which entices students for a better and brighter future [1]. It is crucial that every student must be diligent enough to become a successful seafarer by as much as possible skilled and motivated in every course in the program [2]. Philippines ranks high in producing seafarers working on international merchant ships [3]. But EMSA has conducted monitoring in the maritime industry and the International Maritime Organization (IMO) commits governments to comply with provisions and ensure that the Standards of Training, Certification and Watchkeeping (STCW) was really implemented [4]. This gives tension on the strict monitoring of maritime industry in Asia.

Manuscript received December 24, 2019; revised March 11, 2020.

R. E. Balcita is with the Northern Philippines College for Maritime, Science and Technology, Brgy. Lingsat, San Fernando City, La Union, Philippines 2500 (e-mail: romnelle@gmail.com).

T. D. Palaoag is with the University of the Cordilleras, College of Information Technology, Baguio City, Philippines 2600 (e-mail: tpalaoag@gmail.com).
A research conducted by the International Maritime Organization (IMO) in Hong Kong showed that the maritime education had not reached their pre-established goal. One of the aspects in maritime education development process aims to prepare ship officers and other specialists' is the thorough selection of the learning content according to real life necessities. Therefore, structuring the learning content of the subjects, both significant to profession and conforming to the requirements set by professional bodies, is one of the key issues addressed by curriculum developers [5]. In the Philippines, it has ratified 21 of the 59 different international conventions affecting the welfare of seamen and the shipping industry as a whole. The country was criticized from international bodies like the European Union, on the Philippines' systems and procedures in training and deploying seamen had expressed doubts on the country's ability to abide by the rules laid out in the international conventions that govern the maritime industry all over the world [6].

The education industry could hardly cope up in the new technology because of implemented high cost for using these applications and followed by the lack of knowledge of educators [7]. Educators tend to stick on what is already there, but because of new curriculums being implemented needed to establish new or innovative ways in educating students through adoption and utilization of new and advance technologies [8]. Learning strategies like presentation, multimedia, simulators and hands-on are still common tools used in institutions [9]. These are also mentioned and proven strategies used for teaching and learning strategies [10].

Many under the educational sector make use of visual aids in the form of text, image-based or multimedia representation of images in their lessons and textbooks [11]. The use of technology is not utilized in the education sector [10]. Many advanced technologies can now be used to enhance the learning experience in education. Under visual technology, simulations and multimedia had become more common and there are many others under this field like digital media [12].

Simulator requires separate room to allow limited number of students per session, purchase of tools or equipment for educational purpose is expensive and bulky [13]. This limits learning experience of a learner, the level of experience of a learner varies on the number of exposures incurred. To some students learning becomes less priority as long as they have class attendance, this leads to poor education. Some students volunteer to do activities as representative of their members becomes highly skilled and knowledgeable [14]. There are alternative means of making activities in a one-on-one basis 
aside from hands-on and simulators. But with the increasing number of students a critical issue faced by institutions forces acquisition of additional tools or equipment, or expansion [13].

Advancement of technology today can help improve a lot of ways in the many fields of science and in our daily activities. The introduction of augmented reality in the education sector will change the level of learning of students [15]. Some of the old methods like drawing will be replaced by having a smartphone to view the augmented model of the image more accurately and may engage intuitive learning experience [8]. Student self-motivation is triggered naturally when the need to learn something is inevitable [16].

With the widespread development of visual technology systems this has become one of the major highlights in the software application development industry [17], and the open source community also got involved in system development [18]. The introduction of turning a 2D image into 3D image and into the 4D image is a leap on this technology. This 4D visual image is known as augmented reality, wherein only big companies, industries and commercial businesses benefits most in its capabilities [8].

Applications of AR technology are becoming widespread in medicine. In surgery it delivers surgeons extensive visual and knowledge information to assist a surgical anatomy during an operation [19], it presents knowledge on spine surgery [20] and in pathology the HoloLens is a novel AR tool having multiple clinical and nonclinical [21]. In building construction, using handheld mobile device and a combination of AR technology with building information modeling (BIM) provides a powerful system for construction progress monitoring directly on a construction site [22]. In the education industry, mobile augmented reality is used in geography education in Turkey [23]. Also in Staffordshire in UK, AR and VR showed a great potential in STEM education [24]. AR has become a tool to deliver blended learning experience in life science education [25], and the use of AR has been growing from the industrial revolution 4 up to the coming industrial revolution 5 where artificial intelligence becomes more powerful under augmented reality [26].

The study is based on finding the factors that affects the learning experiences when presentation, multimedia, simulation and hands-on are used for teaching and learning to students pertaining to the use of tools and equipment for marine engineering students. This will enable to introduce advance and smart technologies combined with innovative thinking, the researcher aims to develop an augmented reality framework to alleviate the factors affecting learning experiences of student. The AR model framework can be used to either supplement or to enhance the learning experience of students on any maritime and non-maritime programs in the future. This also helps innovators achieve better learning outcomes of their students by utilizing the use of smart devices and to engage learning during student's vacant times or after class hours.

\section{METHODS}

The survey questionnaire was from the study on student satisfaction by Barbera [27], it was used to evaluate online based learning to determine educational experiences and the subjective students' perception of a course. The questionnaire was revised to cater the learning strategy to be evaluated. Since there were different strategies to be evaluated for every session, the strategies mentioned in the questionnaire were changed so as not to confuse the participants on what strategy was concerned during evaluation. Also, since the focus of the study is on the evaluation of strategies, all questionnaires pertaining to administrative support were removed, this does not concern on student's learning experience.

Then the questionnaire was given to twenty teachers to validate the items with Cronbach's Alpha, which results to 0.874 . The 27-item questionnaire is divided into 6 variables to measure learning strategies and factors affecting learning experiences. All items were scored using the 5-point Likert scale, measuring the extent to which learners strongly disagreed to strongly agree with the statement. The factors identified in the study are divided into six variables that would measure student's satisfaction and learning satisfaction, see Table I. These defines the different areas that influences student learning experiences with regards to learning platform or strategy used during the learning process, at the same time defines the learner's satisfactory level and exposing the efficiency of the learning strategy.

The survey is administered to 32 marine engineering students Northern Philippines College for Maritime, Science and Technology (NPCMST). The demonstration content is focused on ac motors, where in a 30-minute session was set on every learning strategy used then questionnaires were distributed and collected after every session. Then the next learning strategy was initiated repeating the same procedure up to the last learning strategy. In the data analysis, SPSS is used to compute for the statistical mean of the obtained data.

TABLE I: LEARNING STRATEGY VARIABLES

\begin{tabular}{ll}
\hline \hline Variable & Description \\
\hline Learning platform (LP) & $\begin{array}{l}\text { The technology or material supporting } \\
\text { the educational experience }\end{array}$ \\
Students' interaction (SI) & $\begin{array}{l}\text { Interaction among students } \\
\text { The content to be learned }\end{array}$ \\
Learning content (LC) & $\begin{array}{l}\text { Student's satisfaction with the learning } \\
\text { experience }\end{array}$ \\
Knowledge satisfaction (KS) & $\begin{array}{l}\text { Student's perception of his/her learning } \\
\text { in the educational experience } \\
\text { Ability to transfer (AT) }\end{array}$ \\
& $\begin{array}{l}\text { Student's perception on what extent to } \\
\text { apply the newly acquired knowledge in } \\
\text { new and different contexts }\end{array}$ \\
\hline \hline
\end{tabular}

\section{RESULT AND DISCUSSION}

The revised questionnaire had to be tested to ensure the credibility of the data to be produced for further processes and analysis. Table II shows the summary of results in Cronbach's Alpha of the variables or the different categories of the questionnaire. According to the Cronbach's Alpha interpretation, all values between 0.8 and 0.9 indicate "good" internal consistency, stating that the revised questionnaire is a good tool in obtaining data for statistical analysis.

The average weighted mean of the different learning strategies are summarized in Table III, the results are between 2.00 and 3.00 respectively. Surprisingly the 
researchers' expectations on the learning strategies initiated in the study shows that the participants only "agree" and not "strongly agree" on the satisfaction of the learning strategies. In the appendix, it shows the complete generated result of the weighted mean of the variables in the questionnaire. The values in the table are interpreted as when the values are less than 3.00 then it is better or any values closer to 2.00 are much better.

TABLE II: CRONBACH'S ALPHA RESULT

\begin{tabular}{cc}
\hline \hline Variable & Results \\
\hline Learning Platform & 0.838 \\
Students' Interaction & 0.870 \\
Learning Content & 0.873 \\
Learner Satisfaction & 0.874 \\
Knowledge Satisfaction & 0.876 \\
Ability to Transfer & 0.875 \\
\hline \hline
\end{tabular}

TABLE III: SUMMARY OF LEARNING STRATEGIES

\begin{tabular}{llcccc}
\hline \hline Variables & & $\mathrm{P}$ & $\mathrm{M}$ & $\mathrm{S}$ & $\mathrm{H}$ \\
\hline LP & Learning platform & 2.78 & 2.52 & 2.47 & 2.78 \\
SI & Students' interaction & 2.63 & 2.54 & 2.51 & 2.63 \\
LC & Learning content & 2.59 & 2.34 & 2.51 & 2.59 \\
LS & Learner satisfaction & 2.37 & 2.36 & 2.30 & 2.37 \\
KS & Knowledge satisfaction & 2.56 & 2.40 & 2.48 & 2.56 \\
AT & Ability to transfer & 2.47 & 2.51 & 2.39 & 2.47 \\
& Average mean & 2.57 & 2.45 & 2.44 & 2.57 \\
\hline \hline
\end{tabular}

The average mean in Table III, show a small significant difference on the learning strategies, simulation (2.44) as the preferred strategy followed by multimedia (2.45), presentation (2.57) and hands-on (2.57) which proves that there are problems encountered by the students during the different areas in learning and teaching strategies. In the learning platform, the use of a simulator (2.47) is more preferred than multimedia (2.52), hands-on (2.78) or presentation (2.78). In students' interaction, simulation (2.51) shows a better impact on students' participation among their peers, followed by multimedia (2.54), presentation (2.63) and hands-on (2.63). In the learning content, most of the participants preferred multimedia (2.34) next is simulator (2.51). Under learner satisfaction, simulator (2.30) is more preferred than multimedia (2.40), presentation (2.37) and hands-on (2.37). In knowledge satisfaction of the participants, multimedia (2.40) was preferred than simulator (2.48), presentation (2.56) and hands-on (2.56). And the ability to transfer, simulator (2.39) has been preferred rather than presentation (2.47), hands-on (2.47), and multimedia (2.51) respectively.

TABLE IV: STATISTICAL MEAN OF LEARNING PLATFORM

\begin{tabular}{llcccc}
\hline \hline \multicolumn{2}{l}{ Variables } & P & M & S & H \\
\hline LP1 & All important content was easy ... & 2.50 & 2.53 & 2.56 & 2.41 \\
LP2 & The strategy provides clear means... & 2.81 & 2.47 & 2.34 & 2.72 \\
LP3 & Strategy is appropriate for the topic & 2.53 & 2.56 & 2.19 & 2.81 \\
LP4 & Strategy has sufficient time ... & 2.78 & 2.19 & 2.59 & 3.00 \\
LP5 & Strategy does not need further ... & 2.66 & 2.59 & 2.91 & 2.97 \\
\hline \hline
\end{tabular}

To determine a deeper analysis and understanding some reasons that does not agree on the expected results of the study, like multimedia and simulator is better than hands-on. By further exploration in showing the contents of variables LP, LS and KS, it further expounds the reason of such discrepancy of expectations in the results of the study.

All the results in Table IV, Table V and Table VI, show a small significant difference on the different learning strategies. In LP1, hands-on show as the most preferred the learning platform with at least 0.1 difference among the other platforms to convey the content of a topic was easy to locate and identify. In LP2, simulation and multimedia are better than presentation and hands-on with a 0.3 to 0.4 significant difference between but still states that all learning platforms provides clear means of obtaining technical help. Then in LP3, simulation (2.19) is more acceptable strategy in conveying the topic and not the hands-on. But in LP4, multimedia (2.19) was more accepted as a strategy in learning a topic with sufficient time. And in LP5, presentation (2.66) and multimedia (2.59) was preferred and agree on learning without the need of further support.

TABLE V: STATISTICAL MEAN OF LEARNER SATISFACTION

\begin{tabular}{llcccc}
\hline \hline \multicolumn{2}{l}{ Variables } & P & M & S & H \\
\hline LS1 & I was motivated to do well ... & 2.69 & 2.47 & 2.34 & 2.59 \\
LS2 & Course was a useful learning ... & 2.41 & 2.41 & 2.03 & 2.28 \\
LS3 & The course was relevant ... & 2.50 & 2.13 & 2.31 & 2.34 \\
LS4 & I learned from the activities ... & 2.78 & 2.16 & 2.66 & 2.19 \\
LS5 & I recommend that other people ... & 2.66 & 2.34 & 2.44 & 2.44 \\
\hline \hline
\end{tabular}

In learner satisfaction in Table V, LS1 shows simulation (2.34) followed by multimedia (2.47) then hands-on (2.59) and presentation (2.69), because simulation is more detailed in showing internal parts of objects while at work, e.g. engine simulator. LS2 denotes what strategy is useful in the learning experience, simulation (2.03) is the choice followed by hands-on. In the class session of the course simulation can be repeated several times to master skill, but during hands-on a time limit is set on every student. LS3 denotes the course if relevant to their needs showing that multimedia (2.18) is the preferred strategy in this field. LS4 measures learned activities, both multimedia (2.16) and hands-on (2.19) are preferred. LS5 denotes if the strategy is recommended, multimedia (2.34) as the most preferred followed by simulation (2.44) and hands-on (2.44).

TABLE VI: STATISTICAL MEAN OF KNOWLEDGE SATISFACTION

\begin{tabular}{llcccc}
\hline \hline Variables & P & M & S & H \\
\hline KS1 & I did well on class ... & 2.72 & 2.28 & 2.19 & 2.52 \\
KS2 & I can explain the material covered... & 2.44 & 2.34 & 2.47 & 2.44 \\
KS3 & I have noticed the difference... & 2.34 & 2.63 & 2.47 & 2.75 \\
KS4 & During the course, I have been... & 2.56 & 2.41 & 2.28 & 2.53 \\
KS5 & I can make correct decisions and ... & 2.44 & 2.75 & 2.59 & 2.53 \\
\hline \hline
\end{tabular}

Under knowledge satisfaction in Table VI, where KS1 denotes class participation, simulation (2.19) students are more participative in this strategy, followed by multimedia (2.28), then hands-on (2.53) and presentation (2.72). This must be recurring through an area that is necessary to understand certain topic. KS2 denotes the ability to explain the material to others, multimedia (2.34) is more preferred and a 0.1 difference among the other strategies. KS3 denotes the level of knowledge gained, presentation (2.34) is preferred, stating technical terms are better found in this strategy rather on simulation (2.47), multimedia (2.63) and hands-on (2.75). KS4 is the awareness of learning strengths and weaknesses, simulation (2.28) is the choice in this area, followed by multimedia (2.41), hands-on (2.53) and presentation (2.56) suggests that the strategy is best suited for repetitive tasks to learn. And KS5 denotes the ability to apply 
what is learned, suggesting that presentation (2.44) is preferred, then hands-on (2.53), simulation (2.59), and multimedia (2.65).

As a result, using presentation alone during learning is not enough to satisfy students, also with multimedia, the data shows that simulation and hands-on is the most preferred but in the data analysis, none of the strategies has achieved lesser than 2.00. This means that these strategies need improvement, implement supporting strategies, combination of strategies, or strategy innovation using their smartphones.

Therefore, a need to design a framework that can be used to supplement the learning strategies used whenever there are problems encountered during a topic delivery. In Fig. 1, is the proposed designed research AR model framework to be the guide in evaluating each strategy used in the learning process The participants had to evaluate the learning strategy used through a questionnaire, then the data gathered is statistically analyzed to determine if the strategy needs further enhancement or will serve as a learning supplement. An AR prototype model will be created and will be assessed to determine if a $2 \mathrm{D}$ or $3 \mathrm{D}$ image developed will enhance learning experience. Once the AR prototype model is created then passes an assessment, the AR model will be uploaded in the internet or stored in the internet for future use, then this can be easily downloaded to their smartphones for personal learning enhancement and experience.

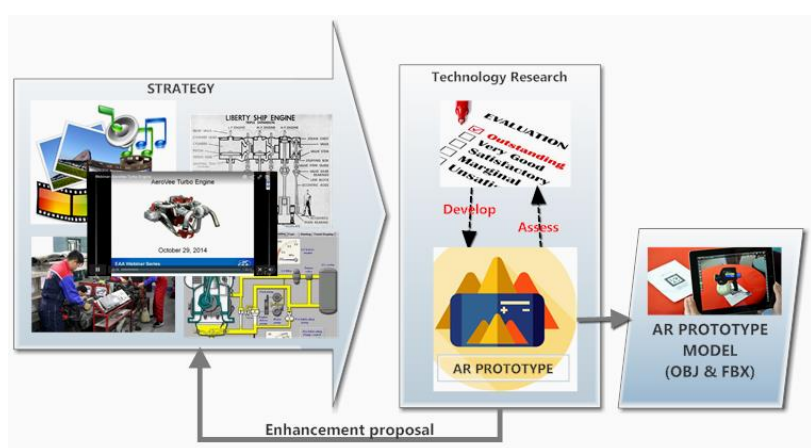

Fig. 1. Proposed augmented reality framework.

Since there are existing non-maritime AR models in the internet, a sample model was selected to show what AR is all about and, there were positive reactions and feedbacks from students and teachers regarding the sample demonstration although it is not related to the learning topic. Therefore, based also on these observations, there is a big opportunity for the education sector to adopt and make use of AR models to enhance learning experiences.

In the sequence of using the proposed AR framework, if there are objects such as major tools or major equipment that needs supporting information for learning, an AR prototype created will be shown to several teachers and deans for evaluation and obtain suggestions for the improvement of the model. This AR model will not be used until all were satisfied with the visual presentation of the AR model.

\section{CONCLUSIONS AND RECOMMENDATIONS}

In this study conducted, it shows that there are factors affecting learning experience of students under maritime education. Also shows that even one of the learning strategies are not enough to satisfy the learning experiences of the students because the experiment proves that the strategies mentioned did not go beyond the researchers expectations. The results almost stayed at the marginal level of the average means of the statistical data. The result also leads in finding other means to alleviate the factors affecting learning experiences through learning and teaching innovation and the use of smart technology. This supports to make use of visual technology like creating augmented reality models to support the learning gaps and a tool for more intuitive learning. Therefore the AR model framework must be introduced and incorporated for education to achieve better satisfaction in learning with the course. This study also recommends the use of the AR model framework to evaluate the needs of learning strategies to obtain what AR model will be created or enhanced. Further study is needed to determine the effects of combining strategies during teaching, self-studying and use of online video on their phones.

\section{APPENDIX}

\begin{tabular}{|c|c|c|c|c|c|}
\hline \multicolumn{2}{|c|}{ Variables } & \multirow{2}{*}{\begin{tabular}{c|}
$\mathrm{P}$ \\
2.50
\end{tabular}} & \multirow{2}{*}{$\frac{\mathrm{M}}{2.53}$} & \multirow{2}{*}{$\frac{\mathrm{S}}{2.56}$} & \multirow{2}{*}{$\frac{\mathrm{H}}{2.41}$} \\
\hline LP1 & $\begin{array}{l}\text { All important content was easy to } \\
\text { locate and identify. }\end{array}$ & & & & \\
\hline LP2 & $\begin{array}{l}\text { The strategy provides clear means of } \\
\text { obtaining technical help. }\end{array}$ & 2.81 & 2.47 & 2.34 & 2.72 \\
\hline LP3 & Strategy is appropriate for the topic. & 2.53 & 2.56 & 2.19 & 2.81 \\
\hline LP4 & $\begin{array}{l}\text { Strategy has sufficient time for } \\
\text { discussions. }\end{array}$ & 2.78 & 2.19 & 2.59 & 3.00 \\
\hline LP5 & Strategy does not need further support. & 2.66 & 2.59 & 2.91 & 2.97 \\
\hline SI1 & $\begin{array}{l}\text { Comments by other participants } \\
\text { helped me learn. }\end{array}$ & 2.88 & 2.38 & 2.56 & 2.63 \\
\hline $\mathrm{SI} 2$ & $\begin{array}{l}\text { I contributed to the learning } \\
\text { environment by responding to my } \\
\text { peers. }\end{array}$ & 2.81 & 2.34 & 2.34 & 2.72 \\
\hline SI3 & I learned to value other points of view. & 2.94 & 2.81 & 2.72 & 2.53 \\
\hline LC1 & $\begin{array}{l}\text { Content was presented at an } \\
\text { appropriate level for me. }\end{array}$ & 2.28 & 2.81 & 2.47 & 2.53 \\
\hline $\mathrm{LC} 2$ & $\begin{array}{l}\text { Content was relevant to the objectives } \\
\text { of the course. }\end{array}$ & 2.72 & 2.56 & 2.31 & 2.25 \\
\hline LC3 & $\begin{array}{l}\text { Content was stimulating to me as a } \\
\text { learner. }\end{array}$ & 2.63 & 2.13 & 2.25 & 2.22 \\
\hline $\mathrm{LC} 4$ & $\begin{array}{l}\text { Content was appropriate on the } \\
\text { strategy. }\end{array}$ & 2.56 & 2.63 & 2.41 & 2.97 \\
\hline LS1 & Motivated to do well in this course. & 2.69 & 2.47 & 2.34 & 2.59 \\
\hline LS2 & $\begin{array}{l}\text { This course was a useful learning } \\
\text { experience. }\end{array}$ & 2.41 & 2.41 & 2.03 & 2.28 \\
\hline LS3 & Course was relevant to my needs. & 2.50 & 2.13 & 2.31 & 2.34 \\
\hline LS4 & $\begin{array}{l}\text { I learned from the activities assigned } \\
\text { in the course. }\end{array}$ & 2.78 & 2.16 & 2.66 & 2.19 \\
\hline LS5 & $\begin{array}{l}\text { I recommend that other people use the } \\
\text { strategy. }\end{array}$ & 2.66 & 2.34 & 2.44 & 2.44 \\
\hline KS1 & $\begin{array}{l}\text { I did well on class participation, } \\
\text { discussion or quizzes. }\end{array}$ & 2.72 & 2.28 & 2.19 & 2.52 \\
\hline $\mathrm{KS} 2$ & $\begin{array}{l}\text { I can explain the material covered in } \\
\text { this course to others. }\end{array}$ & 2.44 & 2.34 & 2.47 & 2.44 \\
\hline KS3 & $\begin{array}{l}\text { Have noticed the difference of prior } \\
\text { knowledge and the knowledge gained } \\
\text { in the end of the course. }\end{array}$ & 2.34 & 2.63 & 2.47 & 2.75 \\
\hline KS4 & $\begin{array}{l}\text { During the course, I have been } \\
\text { conscious about my strengths and } \\
\text { weaknesses in my learning. }\end{array}$ & 2.56 & 2.41 & 2.28 & 2.53 \\
\hline KS5 & $\begin{array}{l}\text { I can make correct decisions and solve } \\
\text { problems with the knowledge I have } \\
\text { gained in this course. }\end{array}$ & 2.44 & 2.75 & 2.59 & 2.53 \\
\hline AT1 & $\begin{array}{l}\text { I know how I will use the course } \\
\text { material in new situations. }\end{array}$ & 2.63 & 2.34 & 2.19 & 2.56 \\
\hline AT2 & $\begin{array}{l}\text { As a result of this course, I am able to } \\
\text { apply my learning to other, similar } \\
\text { courses. }\end{array}$ & 2.53 & 2.22 & 2.44 & 2.28 \\
\hline AT3 & $\begin{array}{l}\text { I have opportunities to apply the } \\
\text { course material. }\end{array}$ & 2.38 & 2.50 & 2.63 & 2.19 \\
\hline AT4 & With the knowledge gained from this & 2.50 & 2.41 & 2.53 & 2.47 \\
\hline
\end{tabular}


course, I can more broadly explore a problem in the field of study.

$\begin{array}{lllll}\text { AT5 As a result of this course, I am able to } & 2.59 & 2.50 & 2.78 & 2.84\end{array}$ apply my learning to a different context, such as my personal or professional life.

\section{CONFLICT OF INTEREST}

The authors declare that there is no conflict of interest.

\section{AUTHOR CONTRIBUTIONS}

Rommel Balcita has conducted the research, analyzed the data and wrote the paper. Thelma Palaoag is the paper adviser, organized the research content and made important revisions; all authors had approved the final version.

\section{REFERENCES}

[1] L. Edirisinghe, N. Jayakody, L. Ranwaka, Lakshmi, and S. Lixin, "Factors that determines the students' choice of maritime education and training with special reference to seafaring officers," in Proc. Dalian Maritime University Maritime Training/Education Conference, October 2016.

[2] A. Atienza, J. Flores, P. Manalo, T. Bacay, M. R. Tamayo, and J. Laguador, "Relationship between maritime students' attitude towards school related factors and academic performance," Asia Pacific Journal of Maritime Education, vol. 3, no. 1, pp. 31-37, June 2017.

[3] N. Tarrazona, "India, Philippines compete for global share of seafarers," The Maritime Executive, pp. 21-43, June 2017.

[4] M. H. Wanga and C. Clive, "Effects of the standards of training, certification and watchkeeping for seafarers (STCW) 78 convention, as amended, on Kenya's maritime education and training (MET)," World Maritime University Dissertations, 2015.

[5] R. Kalnina and V. Priednieks, "Proficiency improvement method in maritime education," WMU Journal of Maritime Affairs IAMU Section Article, October 2017.

[6] M. Cruz. (September 2018). PH short of commitment to IMO. Manila Standards. [Online]. Available: http://manilastandard.net/news/national/276503/-ph-short-of-commit ment-to-imo-.html

[7] L. Zhiminhe, H. Peng, M. Han, and Z. Zhang, "Design and implementation of augmented reality cloud platform system for 3D entity objects," Procedia Computer Science, vol. 131, pp. 108-115, April 2018

[8] A. Iftene and D. Trandabăt, "Enhancing the attractiveness of learning through augmented reality," Procedia Computer Science, vol. 126, pp. 166-175, July 2018.

[9] P. A. Ertmer, A. T. Leftwich, O. Sadik, E. Sendurur, and P. Sendurur, "Teacher beliefs and technology integration practices: A critical relationship," Computers \& Education, Science Direct, vol. 59, no. 2, pp. 423-435, September 2012.

[10] L. Sousa, B. Richter, and C. Nel, "The effect of multimedia use on the teaching and learning of social sciences at tertiary level: A case study," Yesterday and Today, vol. 17, July 2017.

[11] K. Evers, J. Golding, and G. Grima, "Opportunities for teaching and learning with digital resources: What and why," in Proc. BCME9 BSRLM, November 2018, pp. 48-55.

[12] JISC. (June 2015). Using digital media in new learning models. JISC Advice Guides. [Online]. Available: https://www.jisc.ac.uk/guides/using-digital-media-in-new-learning-m odels

[13] C. Gudo, M. Olel, and I. Oanda, "University expansion in Kenya and issues of quality education: Challenges and opportunities," SemanticScholar, vol. 2, no. 20, November 2011.

[14] M. Bower, C. Howe, N. McCredie, A. Robinson, and D. Grover, "Augmented reality in education - Cases, places and potentials," Educational Media International, vol. 51, no. 1, pp. 1-15, March 2014.

[15] W. Li, A. Y. C. Nee, and S. K. Ong, "A state-of-the-art review of augmented reality in engineering analysis and simulation," Multimodal Technologies and Interaction, vol. 1, no. 3, p. 17, 2017
[16] E. Sean. (2009). Effects of interaction on students' perceived learning satisfaction in university online education: An empirical investigation. AIS Electronic Library (AISeL). [Online]. p. 33. Available: http://aisel.aisnet.org/siged2009/33

[17] J. Palacios, F. Morabito, and D. Remondino, "Access to complex reality-based 3D models using virtual reality solutions," Journal of Cultural Heritage, vol. 23, pp. 40-48, October 2016.

[18] H. Pope. (2014). Introduction to virtual and augmented reality. ALA TechSource. [Online]. 54(6). Available: https://www.slideshare.net/catthmd/cgma-skill-share-css-introductionto-augmented-reality

[19] B. Fida, F. Cutolo, G. Franco, M. Ferrari, and V. Ferrari, "Augmented reality in open surgery," Updates in Surgery, vol. 70, no. 3, pp. 389-400, September 2018.

[20] S. M. Park, H. J. Kim, J. S. Yeom, and Y. G. Shin, "Spine surgery using augmented reality," Journal of Korean Society of Spine Surgery, vol. 26, no. 1, pp. 26-32, March 2019.

[21] M. G. Hanna, I. Ahmed, J. Nine, S. Prajapati, and L. Pantanowitz, "Augmented reality technology using Microsoft Hololens in anatomic pathology," Pathology \& Laboratory Medicine, vol. 142, no. 5, pp. 638-644, May 2018.

[22] M. Zaher, D. Greenwood, and M. Marzouk, "Mobile augmented reality applications for construction projects," Construction Innovation, vol. 18, no. 2, pp. 152-166, April 2018.

[23] Z. Turan, E. Meral, and I. Fevzi Sahin, "The impact of mobile augmented reality in geography education: Achievements, cognitive loads and views of university students," Journal of Geography in Higher Education, vol. 42, no. 3, pp. 427-441, March 2018.

[24] R. Al-Azawi, A. Ablbadi, R. Moghaddas, and J. Westlake, "Exploring the potential of using augmented reality and virtual reality for STEM education," Learning Technology for Education Challenges, pp. 36-44, May 2019

[25] J. Barrow, C. Forker, A. Sands, D. O'Hare, and W. Hurst, "Augmented reality for enhancing life science education," in Proc. VISUAL 2019 the Fourth International Conference on Applications and Systems of Visual Paradigms, March 2019.

[26] S. Nahavandi, "Industry 5.0-A human-centric solution," Sustainability, vol. 11, no. 16, p. 4371, August 2019.

[27] E. Barbera, M. Clarà, and J. Linder-Vanberschot, "Factors influencing student satisfaction and perceived learning in online courses," E-Learning and Digital Media, November 2013

Copyright (C) 2020 by the authors. This is an open access article distributed under the Creative Commons Attribution License which permits unrestricted use, distribution, and reproduction in any medium, provided the original work is properly cited ( $\mathrm{CC} \mathrm{BY} \mathrm{4.0})$.

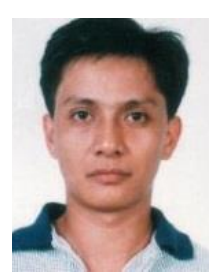

Rommel E. Balcita was born in Bokod, Benguet, Philippines on August 7, 1972. He finished primary school at Bobok Sawmill Elementary School at Bokod Benguet, Philippines, and secondary school at Tubao National High School at Tubao, La Union, Phils. Then he graduated with a bachelor of science in computer science from Agoo Computer College at Agoo, La Union, Phils. And he finished the master of information technology in 2017 at the University of the Cordilleras, Baguio City, Phils. major in ERP. Currently he is working as an instructor at Northern Philippines College for Maritime, Science and Technology, Lingsat, San Fernando City, La Union, Philippines. He is the co-author of 2 papers: "Employee-Client Service Management Evaluation Based on Facial Recognition" and "School Intrusion Notification and Alarm System Using Face Recognition", both presented at (WCSE 2018) Bangkok, 28-30 June, 2018 .

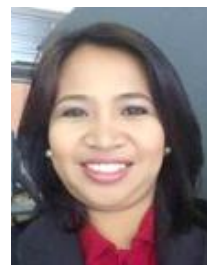

Thelma Domingo Palaoag is the head of Computer Science Department, College of Information Technology and Computer Science, University of the Cordilleras, Baguio City, Philippines. She is a college research coordinator and her research fields include intelligent systems, data analytics, educational technology, e-learning, natural language process. 